9. Henry Dunant, A Memory of Solferino (American Red Cross, 1939; Geneva: The International Committee of the Red Cross, English Version, 1953), 73.

10. For a detailed study of contemporary humanitarian ethics, see Hugo Slim, Humanitarian Ethics: A Guide to the Morality of Aid in War and Disaster (Oxford: Oxford University Press, 2015).

11. See Michael Barnett, Empire of Humanity: A History of Humanitarianism (Ithaca: Cornell University Press, 2011), 40.

12. Thomas W. Laqueur, "Bodies, Details, and the Humanitarian Narrative," in The New Cultural History, ed. Lynn Hunt (Berkeley: University of California Press, 1989), 176-204, 176-78.

13. Barnett, Empire of Humanity, 9.

14. Caroline Shaw, Britannia's Embrace: Modern Humanitarianism and the Imperial Origins of Refugee Relief (Oxford: Oxford University Press, 2015).

15. Lester and Dussart, Colonization, 10, 115.

16. Internment camps were also used by Spanish, American, Italian, and German military authorities in colonial conflicts during this period; see Kristen McConnachie, "Camps of Containment: A Genealogy of the Refugee Camp," Humanity: An International Journal of Human Rights, Humanitarianism, and Development 7, no. 3 (2016): 397-412, 402-04.

17. On the improvised development of colonial legal governance, see Lauren Benton and Lisa Ford, Rage for Order: The British Empire and the Origins of International Law 1800-1850 (Cambridge: Harvard University Press, 2016).

\title{
Ideology
}

\section{ZACHARY SAMALIN}

$\mathrm{F}$ EW concepts are more deeply rooted in the social and intellectual terrain of the nineteenth century than ideology, and yet there can be no question that the political circumstances of the present demand a working conception of ideology with as much urgency as ever before. When we look into what is meant by the term, then, we also raise a set 
of questions about the extent to which the contemporary social world continues to be shaped by structures and problems originating in the tumult of the nineteenth century.

In its most common usage, derived from Karl Marx and Friedrich Engels, the concept of ideology denotes the fact that certain aspects of a thought process which seem to originate in one's own psyche are in fact socially and historically conditioned; what feels personal and individual is revealed to be collective and to originate outside the self. As Engels described it, "Ideology is a process accomplished by the so-called thinker consciously, indeed, but with a false consciousness. The real motives impelling him remain unknown to him ... Hence he imagines false or apparent motives." ${ }^{1}$ In the history of Marxist theory, this notion of false consciousness has proved to be as influential as problematic, raising vexed questions about who is entitled to ascribe such mystified psychological states to whom, and on what grounds; it is also this dimension of ideology that invited various attempts at integration with psychoanalytic theory throughout the twentieth century.

However, what was most significant in Engels's formulation was that the notion of ideology pointed beyond the psychological domain, even as it seemed to demand some account of how consciousness functioned. In The German Ideology, Marx and Engels asserted that the value of ideas derives from the basic organization of a society-the division of laborand not merely from some quality inherent in the ideas themselves. To imagine that religious, legal, or aesthetic values were intrinsic to their own domains, and not expressive in some way of socioeconomic structures, they argued, was to fall prey to ideology. Unlike the problem of false consciousness, which zooms in on the subject, this aspect of ideology sits at the root of modern sociological theory, since it imbricates the individual in a larger web of associations. This conceptual ambivalence makes ideology seem at times a deterministic theory of consciousness, at others a relational account of the interpenetration of different areas of social life. It is most useful to think of the concept as providing a hinge between these two different registers of theoretical explanation.

The whole complex of questions put into play by the consideration of ideology should be seen as arising out of the specific social upheavals of the nineteenth century. As Karl Mannheim observed in his landmark analysis, Ideology and Utopia, the most fundamental shift in this respect was the secularization of the social-epistemological function of religion. Prior to the modern period, Mannheim argued, matters of truth, error and false belief were addressed primarily within the religious domain, 
whereas in the nineteenth century the adjudication of reality fell increasingly under the aegis of "an ontology derived from political experience," on the one hand, and from scientific practice on the other. ${ }^{2}$ Today, it is perhaps easier to see how Victorian-era scientific advances wrested epistemological authority from religion. Yet in Marx, the concept of ideology first emerges through the extension of Ludwig Feuerbach's critique of religion to the analysis of socioeconomic institutions. Indeed, there is a secularization narrative baked into Marx's earliest thinking about ideology, which presupposes secularization as the condition of modern life enabling one to see not only that religion is an ideological structure, but that economic relations in particular enact an organizing function in society.

Over the course of the nineteenth century, then, political action and social life became the dominant domains of experience for the arbitration of certain forms of non-scientific knowledge. The allegation of ideology reflects this transformation, insofar as it derides some ideas as groundless "echoes" and "phantoms," while categorizing others as legitimately rooted in material reality. ${ }^{3}$ Marx's distinction between a philosophy that interprets the world and one that changes it also expresses this historical reprioritization of political experience. Mannheim observes that these shifting intellectual priorities themselves reflect the period's extreme political turbulence. "Only in a world in upheaval," he writes, "in which fundamental new values are being created and destroyed, can intellectual conflict go so far that antagonists will seek to annihilate not merely the specific beliefs and attitudes of one another, but also the real intellectual foundations upon which these beliefs and attitudes rest." 4

In this regard, ideology emerged to address the particular needs of a nineteenth-century lifeworld in which new ideas about the relationship between economy and society were supplanting critical analysis of the weakening relationship between church and state, against an unstable backdrop of industrial immiseration, perpetual war, scientific progress, imperial rapacity, and a political whirlwind of utopian hopes, incremental change, and authoritarian relapse. We are thus certainly justified in asking to what degree the concept retains its explanatory purchase in a current moment defined less by expansion or tumult than by the slow, steady scavenging of the liberal state, and an extractive capitalism that relies less and less on the forms of labor power associated with nineteenth-century industry. Has our social reality changed faster than the tools we use to analyze it? 
Significantly, there is an aspect of ideology critique especially suited to answering this question. For while the historical shifts that yielded the concept of ideology were specific to the nineteenth century, these transformations also signaled a fundamental movement away from theorizing the social in terms of timeless and unchanging values, and instead towards the recognition of historical change itself as the ground for epistemological experience. That is, it was the effect of particular historical changes to allow historical change per se to emerge as a category seen to have a determining effect on the foundations of what people think, value, and deem to be true. In this context, it is less useful to speak of false consciousness than it is to observe that ideas which might have had significant nonideological social functions in the past can nevertheless become ideological over time. Ideology here refers to a form of knowledge that clings to outmoded verities while simultaneously disavowing historical change. As Mannheim puts it, "from this standpoint, knowledge is distorted and ideological when it fails to take account of the new realities applying to a situation, and when it attempts to conceal them by thinking of them in categories which are inappropriate."

Our contemporary society is saturated by this kind of stubborn yet brittle ideological thinking. In the American context, it is apparent in the way that certain liberal-democratic ideals, such as the freedom of speech, will be defended as unalterable pillars of culture even as they are continually mobilized in new ways by antidemocratic economic forces. In such instances, defense of the status quo through the appeal to the timelessness of ideals serves to obfuscate the fact of real change. In the case of freedom of speech so prominent today, people who reflexively defend the right of neo-Nazis to hold armed assemblies under the First Amendment fail not only to see the ways in which harmful speech and violent action converge, but also to recognize that the whole category of speech has been actively reoriented in recent decades in order to accommodate exploitative free market interests. It is not hard to imagine a near future in which the legitimate ideal of a society free from state censorship is entirely repurposed in order to defend the reactionary interests who are today its most ardent proponents. What is ideological in such cases is the refusal to recognize how the social function of an idea is subject to historical changes that transcend the horizons of its internal coherence, its moral value, or its truth. Even when our most vital ideas appear grounded in our social reality, the enduring lesson of ideology critique is that when the ground moves, it drags us as well as our ideas along for the ride. 


\section{Notes}

1. Friedrich Engels to Franz Mehring, London, July 14, 1893, in Marx and Engels Collected Works, Vol. 50 (London: Lawrence and Wishart, 2010), 164.

2. Karl Mannheim, Ideology and Utopia: An Introduction to the Sociology of Knowledge (New York: Harcourt, 1936), 73.

3. Karl Marx, The German Ideology (New York: Prometheus Books, 1998), 42.

4. Mannheim, Ideology and Utopia, 64.

5. Mannheim, Ideology and Utopia, 96.

\section{Image}

LINDA M. SHIRES

The past is not dead, but is living in us, and will be alive in the future which we are now helping to make.

—William Morris, "Preface," Medieval Lore from Bartholomew Anglicus. ${ }^{1}$

D ROMPTED by the word image, this mini-essay recalls a Greco-Roman legacy of the sister arts. ${ }^{2}$ While the Victorians creatively expanded the relationship between the visual and the verbal, we reconceive such a relationship again in our digital era. The nineteenth century witnessed an increase of illustrated texts. Poems inspired art, paintings inspired poems, and painters appended verses to artworks. The Pre-Raphaelite arts and crafts movement was born. Victorians flourished as satirical cartoonists; illustrated magazines and novels thrived; museum reforms engaged Parliament commissions and journalists. Developments in color theory fostered ideas about how the eye works with light, while optical devices replaced the camera obscura's focus on interiority. Color-makers created new pigments. In fact, as Martin Meisel remarked, the century's collaboration between storytelling and image-making markedly characterized theater, literature and art. $^{3}$ Additionally, the visual arts helped shape, not simply illustrate, science, including the mind sciences, and numerous other fields. Notably, too, the 2017 John Lockwood Kipling exhibit at the Victoria and Albert Museum/Bard Graduate Center reveals the complexity 